\title{
Informal urbanism in the state of uncertainty: forms of informality and urban health emergencies
}

\author{
Hesam Kamalipour ${ }^{1} \cdot$ Nastaran Peimani ${ }^{2}$ \\ Accepted: 9 November 2020 / Published online: 7 December 2020 \\ (c) Springer Nature Limited 2020
}

\begin{abstract}
Forms of informality—ranging from informal settlements to street vending and informal transport—have become integral, yet not necessarily limited to how cities of the global South work. Our aim in this paper is to explore the dynamics of informal urbanism in the face of the COVID-19 pandemic and the extent to which forms of informality can adapt in the state of uncertainty. This paper lies in the intersections of informal urbanism and urban design in relation to public health emergencies. This is an exploratory paper in nature, structured in three main sections to focus on the implications of the Coronavirus pandemic on informal settlements, street vending, and informal transport, respectively. We point to how different forms of informality work across cities and conclude by outlining some key considerations and discussing the role of urban design in addressing the capacities and challenges of informal urbanism in the state of uncertainty facing public health emergencies such as the Coronavirus pandemic.
\end{abstract}

Keywords Informality $\cdot$ Informal urbanism $\cdot$ Public space $\cdot$ Pandemic $\cdot$ COVID-19 $\cdot$ Health $\cdot$ Informal settlement $\cdot$ Street vending $\cdot$ Informal transport

\section{Introduction}

The emergence and spread of the COVID-19 as a global pandemic have substantially changed the ways in which everyday urban life plays out in public space. Many cities have surrendered to fear with deserted public spaces and underused streets in lockdowns upending the longstanding desire of urban design to enable and sustain place vitality. Yet, as many people across the world have resorted to private territories, neighbourhood streets and public/private interfaces have become an extension of the existing sidewalks to at once enable social exchange and constrain physical encounters. Urban spaces have also become appropriated in

Hesam Kamalipour

kamalipourh@cardiff.ac.uk

Nastaran Peimani

peimanin@ cardiff.ac.uk

1 School of Geography and Planning, Cardiff University, Room 2.98 Glamorgan Building South, King Edward VII Avenue, Cardiff CF10 3WA, UK

2 Welsh School of Architecture, Cardiff University, Room 1.33 Bute Building, King Edward VII Avenue, Cardiff CF10 3NB, UK different ways, from resorting to private modes of mobility, ranging from scooters and bikes to private cars, to exploring the existing amenities such as neighbourhood parks and local shops within walkable catchment areas in proximity to places of living. While cities have been considered as the key nodes struggling with the COVID-19 outbreak, it is still too soon to make rigorous conclusions about the spatial and temporal implications of the COVID-19 pandemic as the related data is often partial or limited to particular places or scales.

A crisis period at once demands immediate actions and calls for critical reflections on its capacity to intensify preexisting conditions. The history of past crises shows that the most vulnerable are likely to suffer most severely (Sanderson 2020). While insecurity, poverty, and inequalities are particularly striking in the context of informal settlements, they are not necessarily limited to cities of the global South (Acuto 2020). A recent study in Great Britain (Bowyer et al. 2020) observes that the predicted COVID-19 severity and prevalence are considerably higher in more deprived and urban areas. It is critical to prioritise policies to address spatial, social, and economic inequalities and exclusions (Wahba et al. 2020). While a range of COVID-19-related restrictions and temporary measures have been rapidly 
imposed across many cities, it is critical to reflect on other pre-existing and creeping restrictions on public space and urban life that have remained less contested and visible as they took place gradually (Iveson 2020).

The emergence of pandemics and managing the condition of urgency seem to legitimise forms of authoritarian decision-making in relation to the governance of place and management of urban life, invoking critical questions about the role of urban design concerning the place and public life in pandemics such as the COVID-19. Marginalised communities and vulnerable groups are likely to become further disadvantaged. Forms of informality are among the activities that are particularly at risk of being narrowly addressed or becoming simply overlooked, ignored, displaced, or evicted. We argue that adopting a wholesale and reductionist approach to informal urbanism can only worsen the existing condition. Our aim in this paper is to explore the ways in which we can harness the productive and adaptive capacities of informal urbanism and manage the challenges different forms of informality face in the state of uncertainty with a focus on the role of urban design in relation to the spatial and temporal implications of the COVID-19 pandemic.

Informal urbanism-ranging from informal settlements to street vending and informal transport-have become integral to how cities work particularly in the context of what is constructed as the global South. Certain forms of urban informality work as resources to manage the pressing challenge of poverty and, as such, become integral to sustain livelihoods. While forms of informality may invoke images of poverty and disorder, they cannot be simply conflated with each other. Urban informality, as Roy (2015, p. 820) puts it, is "a mode of producing and regulating space." It has been estimated (UN-HABITAT 2006) that about one billion people live in places that have largely emerged and consolidated beyond state control in terms of planning, design, construction, and management. Street vending and informal transport also play a key role in informal economy and mobility by providing job opportunities, generating income for the urban poor, and filling the gaps of formal urban development by negotiating space and visibility in the public realm. While there is an extensive body of knowledge in planning, geography, and social sciences focusing on informal urbanism, forms of informality have often remained underexplored in relation to urban design (Chalana 2019; Mukhija 2011; Kamalipour and Peimani 2019a). This paper lies in the intersections of studies on urban design, informal urbanism, and urban health.

We took an exploratory approach to locate the emerging literature focusing on the dynamics of informal urbanism and the ways in which forms of informality work in the context of urban health emergencies. Our initial search to identify the relevant literature was undertaken in AprilJune 2020, yielding a mix of 118 academic publications and emerging discussions in the digital media and news articles. After reaching a degree of saturation and reviewing the related literature, we manually applied exclusion criteria to minimise possible repetitions and enable a balanced mix of academic publications and news articles. This has resulted in identifying a total of 101 relevant literature for this paper. We thematically categorised the identified literature into three primary forms of informal urbanism, including informal settlement, informal street vending, and informal transport. This paper has been mostly written in May-June 2020 during the public health emergency related to the COVID-19 pandemic in the UK. Hence, in addition to academic publications, we relied mostly on emerging discussions in the digital media and news articles at the time.

We adopt assemblage as a theoretical lens offering tools for thinking and analysis. Assemblage has been developed as a body of theory by Delanda (2006, 2016), building upon Deleuze and Guattari (1987). Its implications for urban design and informal urbanism have been further articulated by Dovey $(2010,2012)$. Assemblage thinking engages with the relations between emerging wholes and parts and the ways in which they work in relation to each other across different scales. Assemblages as emerging wholes cannot be simply reduced to their constituting parts. The focus then is on differences and the relations between parts. Assemblage thinking incorporates both actual and possible while avoiding forms of reductionism. Urban assemblages are being made and unmade between intersecting axes of materiality/expression and territorialisation/deterritorialisation (Delanda 2006; Dovey 2012; Kamalipour and Peimani 2015). Each axis then resonates with a range of twofold conceptions. The materiality/expression axis resonates with inseparable spatiality/sociality relations in cities, while territorialisation/deterritorialisation axis resonates with tree/ rhizome, hierarchy/network, striated/smooth, and formal/ informal twofold conceptions (Dovey 2010; Deleuze and Guattari 1987). Assemblage thinking is particularly useful in articulating the relations between informal and formal as it offers a range of twofold conceptions for exploring such relations across different scales. While formality can be considered as a form of stabilisation to claim territories, establish certain identities, and rigidify tree-like hierarchies, urban informality can be explored as a form of destabilisation to produce smooth space, generate emergent forms of identity, and enable rhizome-like networks and lateral relations. Nevertheless, informal/formal relations cannot be simply reduced to a form of dichotomy as urbanism incorporates a mix of informal and formal across different scales and contexts. 


\section{Informal settlements}

Given the challenges of accommodating about one billion people worldwide, informal settlements are among the most vulnerable places to pandemics, such as the COVID19 outbreak. It is often impossible to simply extend the common measures such as community lockdown, physical distancing, self-isolation, and hand washing to informal settlements, which are densely populated and may not have equitable access to sanitation and safe water at the household level and health care services (UN-HABITAT 2020). Informal settlement populations can also have a considerable impact on the transmission of infectious diseases such as influenza in urban areas, as simulated in the context of Delhi (Chen et al. 2016). As pointed out in one of the recent series of the Lancet on the health of people who live in slums, it is critical to focus on slums as 'spatial entities' and promote what is called 'slum health' as a significant topic of research, which has remained understudied (Ezeh et al. 2017; Lilford et al. 2017). Space has been considered as a significant variable in relation to epidemiology in the context of slums (Lilford et al. 2019).

Informal settlements are often associated with high population density, particularly internal density. Some of the common characteristics include families of 2 to 5 people living in single room buildings of about 3 by 4 metres next to each other and often with shared pit latrines and water taps between 5 to 10 families (Mitlin 2020). Residents of informal settlements have much more contact than those who are not living in informal settlements (Weston 2020). According to a report from the city of Nairobi, informal settlements can have a population density of up to about ten times greater than the formal areas nearby (Bird et al. 2017). In Karachi, the original lots, which were mostly 80-120 square metres and single storey, have become apartments of 25-40 square metres ranging from medium-rise to high-rise (Hasan 2020). A study in Mumbai finds a strong association between the occurrence of tuberculosis and poor ventilation and sunlight, particularly in the lower floors (Pardeshi et al. 2020). While dense places have been historically associated with hygiene concerns, the relations between density perceptions and highly contagious infectious disease concerns remained underexplored and poorly understood (Hooper 2020). The COVID-19 pandemic has left many urbanites questioning or making general assumptions about the impact of density on the potential rate of transmission, infection, and mortality (Olsen 2020; Rosenthal 2020). Nevertheless, rushed assumptions, in the absence of empirical evidence, would result in superficial conclusions, particularly in those rapidly growing cities of the global South.

While focusing on terminology or discussing the nuances of the keywords such as informality often remains contained within certain intellectual or political boundaries, it is critical to avoid using terms such as informal settlements, slums, squatters, and shantytowns interchangeably without considering the related contexts, historical connotations and their capacity to evoke a range of intended and unintended narratives and consequences. Using the word 'slum' does not help as it misrepresents the nuances and complexities of urban inequalities and further marginalises the urban poor and low-income places (Mayne 2017). Informality has become a catch-cry for those who are interested in both popular and academic discussions on the future of cities, particularly in the context of the global South. Yet, informality is not necessarily limited to the cities of the global South (Roy 2005; Arefi and Kickert 2019). The conception of urban informality is often imprecise and contributes to urban theory in confined ways (Marx and Kelling 2018). It is then critical to draw attention to a key area of conceptual slippage in the existing literature. As such, one needs to make a distinction between 'need' and 'desire' when it comes to exploring how informality works as practices often undertaken by lower-income urban residents to survive and meet basic needs in contrast to activities mostly carried out by higheror middle-income residents to serve a range of interests related to convenience, entertainment, and leisure (Devlin 2017). While informality can incorporate a range of unplanned and spontaneous activities, it is different from the temporary appropriations of public space, which can be informally or formally organised (Lara-Hernandez et al. 2020). Although emergent practices of the pop-up, guerrilla, and DIY urbanism by the creative class of the rich world to challenge overregulation are vastly different from the subsistence tactics of the ordinary and informal place of the poor in the absence or ignorance of the state, they both cease to exist when confronted with more profitable and valuable uses (Tonkiss 2013). This is not to say that certain practices, such as DIY urbanism, are merely limited to the urban rich. As Jabareen (2014) argues, DIY urbanism is an informal mode of producing space. Drawing on Roy (2015), we adopt urban informality broadly as an emergent way of place production and governance.

The response of many governments to the COVID-19 outbreak has been to impose strict lockdowns or simply ignore the urban poor (Muggah and Florida 2020). Public health concerns, as reported in the case of Accra (McTernan 2014), can also be mobilised by authorities to intensify the threat of eviction and justify ruthless practices of demolition. The necessity of addressing the immediate challenge of pandemics such as COVID-19 can fuel ignorance, forced eviction, demolition, or displacement without considering the productive capacities of informality. Adaptation and social capital are among the critical assets of informal settlements to ensure resilience in the state of uncertainty. Most strategies 
to address pandemics in informal settlements are likely to overlook the existing social network and knowledge while it is critical to utilise the existing assets to prevent possible exposure and share information to co-create solutions (Corburn et al. 2020).

A range of vulnerabilities including epidemiological vulnerabilities (age, gender, comorbidities), transmission vulnerabilities (density, household and social structures, mobility, livelihood, ventilation, water, toilet, sanitation), systemic vulnerabilities (care networks, disabilities, displaced people, gendered impacts, safety and security, mental health, evictions, migrant workers), health system vulnerabilities, and direct vulnerabilities to control measures has been outlined in a recent study by Wilkinson (2020a). Enabling community engagement and considering the reliance of many residences on 'informal health providers' would be critical to effective control of pandemics in the context of informal settlements where formal administrative boundaries or official units of governance appear to be often irrelevant (Wilkinson 2020b). While the key measures for controlling the COVID-19 transmission are more or less similar across different contexts, the tactics are different in informal settlements where residents face the challenges related to adequate space and sanitation as well as eviction and livelihoods, and where local community networks and groups can also become highly organised to advocate for services and collect the required data (Wilkinson 2020a).

The challenge of informal settlements in relation to pandemics cannot be simply addressed in isolation from the broader context of the city. Pandemic-related interventions in the formal city will have a range of intended and unintended consequences for the ways in which informal settlements work. Urbanism mixes informal and formal as they are not dichotomous but rather interrelated across different scales. City-wide lockdowns can put the livelihoods of many people living in informal settlements with limited incomes and savings particularly at risk as cities cease to remain viable as hubs of jobs and opportunities. Making a balance between livelihoods and the lives of people living in informal settlements and working in the informal sector becomes even more challenging during the city-wide lockdowns, as reported in the context of African countries (Zane 2020). In the case of Dharavi, which accommodates about 1.5 million people within 613 hectares, it has been estimated that about 5-10 percent of its population has gone back to their hometowns after the lockdown (Pinto 2020). Returning home for many daily wage workers was the only feasible response necessary to survive the sudden lockdown, particularly given the devastating economic impacts (Priyadarshini and Chaudhury 2020). Exploring the extent to which such workers can possibly stay in their places of origin or return to their places of work to sustain their livelihoods once lockdowns are lifted remains a task for further research.
Informality is a multiplicity incorporating different forms across different contexts. While forms of informality may share similar patterns, it is critical to note that we are dealing with a range of morphological and typological differences when it comes to informal settlements. While space plays a key role in studies focusing on intersections between health and informal settlements, there is an emerging body of knowledge exploring the micromorphologies and spatial typologies of these settlements (Dovey and King 2011; Kamalipour and Dovey 2018; Jones 2019; Ribeiro 1997; Arefi 2011). Making binary distinctions between informal and formal is also a form of reductionism (Roy 2005) as it overlooks a range of inbetween conditions (Dovey and Kamalipour 2018). While informal settlements may share similar social capacities and vulnerabilities in the face of pandemics such as the COVID-19, their diverse micro-morphologies and spatial typologies call for carefully tailored interventions responding to local contexts to avoid prescribing generalised recommendations in the absence of a nuanced understanding of the morphological and typological dynamics at the micro-scale.

Informal settlements have largely remained invisible on official maps and to the gaze of the formal city, among others (Kamalipour and Dovey 2019). This is to say that the official maps and data on informal settlements are incomplete at best and non-existent at worst (Taylor 2020). The capacity of urban mapping to produce spatial knowledge (Dovey et al. 2018) can be harnessed in urban design research focusing on the intersections between informal settlements and health. Producing and updating spatialised data at the small scale in collaboration with residents can play a crucial role in the extent to which appropriate and equitable responses can be developed to meet the specific needs and desires of the local communities. In Kibera, for instance, in the absence of official maps as well as the ongoing challenges to access and conduct field visits, online mapping has served as a key advocacy tool to identify the existing and potential COVID-19-related spatial interventions (Taylor 2020). Incremental adaptations and informal codes are also integral to how informal settlements work (Kamalipour and Dovey 2020), yet they often remain underexplored. Developing effective intervention scenarios in response to pandemics, such as COVID-19, relies on a sophisticated understanding of the micro-morphologies and adaptations across different types of informal settlements. Changes to building densities are inevitably related to the quality of public open space concerning ventilation and sunlight. Enabling physical distancing in the public realm is also related to the permeability and design of the access network in relation to external population density in informal settlements. 


\section{Informal street vending}

In this section, we focus on the spatial and temporal implications of the COVID-19 pandemic on street vending as one of the most widespread forms of informality, attracting a substantial segment of the labour force. About two-thirds of the world's working population was projected to be involved in the informal sector by 2020 (Neuwirth 2011), most of which unfold in public open space. Top-down initiatives out of perceived risk or fear during outbreaks are likely to put the livelihoods of micro informal economies and enterprises at serious risk by constraining the transactions between street vendors and their potential customers (Ahmed et al. 2019a). The imposed lockdowns and various types of curfews have put an unprecedented halt to the economic livelihood of the street vendors for whom the rights to use (both physical and social) and appropriate public space can create employment and entrepreneurial opportunities. While vendors are often stigmatised for offering unsafe food, they play a key role in the food security of informal settlements, as shown in Nairobi, Kenya (Ahmed et al. 2019b). In many cities, the rapid and radical response to this COVID-19 outbreak has been to enforce policies to crack down on street vendors and eliminate large numbers of such invisible workers from public spaces where they are no longer able to secure a job and earn a decent livelihood with a certain degree of autonomy in their working lives.

Despite attempts at controlling public space through clearing vending practices away, a significant number of formal food businesses have remained open. Such formal businesses have been permitted to offer service to the public (including key workers) as long as they adhere to the governments' social distancing guidance through using contactless delivery or takeaway options. Nonetheless, in many places such as Vietnam, the informal food market and street vendors are deemed as unhygienic activities and the appropriated public spaces as hot spots for virus transmission (Wertheim-Heck 2020). This has pushed the earnings of informal street vendors in several cases, such as Bangkok, down to about $80 \%$ (Taylor and Chandran 2020). One could argue that the intervention of the Coronavirus justifies another story of eviction - this time under the guise of public health and safety crises. This resonates with what Latour (2020) describes as "the self-evident sense of protection" - a narrative of legitimacy that the state uses to maintain the image of an 'ordered' city during the pandemics.

Addressing street vending should involve recognition of their agency in food security as well as their rights to use and appropriate public space, particularly in those curfew wards of the city that there are a limited number of supermarkets/grocery stores within walkable catchments of residential areas. This can contribute to a more equitable distribution of micro-scale amenities. Nevertheless, hasty responses from policymakers, seeking to favour macro-scale formal businesses while limiting micro-scale informal enterprises, are generally based on a range of rarely evidence-based or locally contextualised assumptions that link informal markets to unsafe food (Ahmed et al. 2019a). A recent study shows that the transmission of COVID-19 is mainly through an extended close encounter between individuals and via the fomite route within indoor environments (e.g. enclosed workspace, public transport, restaurants) (Qian et al 2020). Recent outbreaks spread reported from outdoor spaces seem to be responsible for a small percentage of all traced infections. As such, enabling opportunities for street vendors to appropriate public open spaces to sell necessary products in close proximity to where people live and work ('essential' businesses) appears to carry less risk of infection transmission. Such attempts are now more than ever a matter of survival to the urban poor and low-skilled rural-to-urban migrants. In addition, their sustained livelihood can save on transport costs, provide more affordable access to essential food and goods than those at formal wet markets or supermarkets/ grocery stores (particularly for low-income urbanites), and ensure the compliance with the unprecedented social distancing restrictions during the lockdown.

Exposure to the COVID-19 pandemic has induced the need to explore possible forms and capacities for adaptation in our cities and make them more resilient to future public health crises. As a seminal metaphor to understand the dynamics of informal vending in public space, resilience here links to how micro-scale design of streetscapes can adapt to emerging and changing sets of forms, functions, and forces, resulting from either top-down planned interventions or bottom-up processes. Examples of this include, but not limited to, introducing 'vegetables on wheels' innovative initiative to deliver survival goods and services on e-rickshaws to curfew areas of the city (Chen 2020), and reallocating road spaces from cars to a network of temporary vending areas compatible with the restrictions on the use of public space and social distancing measures in Kalaw town in Myanmar (Nyein 2020). Notably, many non-food vendors have shifted to offering survival items, including food, fruits, vegetables, and water cans that are less affected by the lockdown. Nevertheless, the key questions here are about the extent to which the current survival tactics might change once the lockdown restrictions are eased, and how the livelihoods of those food vendors can be sustained if fewer residents choose street food due to health and hygiene concerns.

Now is the time to rethink and perhaps reinvent some of our assumptions and recurrent guidelines about the use and 
appropriation of public open spaces by street vendors and the opportunities they provide for urban public life. If adherence to such guidelines is closely monitored and local regulations prohibiting street vending are lifted, they can keep vendors afloat where their livelihood thrives even more safely than other indoor markets or grocery stores during the COVID19 pandemic. We argue that such guidelines should be more type based, with a particular focus on mobility within public space and proximity to public/private urban interfaces or the edge of public space (Kamalipour and Peimani 2019b), while ensuring a degree of fairness in providing both female and male vendors with equitable access to public space. So far, the most surviving patterns of street vending during the COVID-19 pandemic appear to be the ones with limited mobility capacity. An example of this is the predominance of unfixed and semi-fixed vending types in cities where roadways are opened to pedestrians and street vendors to provide additional space for physical and social distancing. Another key criterion that becomes crucial for spatial claims of vendors is the extent to which their proximity to different types of public/private urban interfaces can have an impact on the opportunities afforded in public space. During the pandemic, the reallocation of roadways to pedestrians enables a retail opportunity between different types of vendors and flows of potential customers. These types include those detached/ unfixed or detached/semi-fixed with higher adaptability to comply with the physical and social distancing measures. Other more adjacent types of vendors (adjacent/unfixed and adjacent/semi-fixed) can also appropriate shopfronts. The capacity of this type for negotiating visibility can increase as the majority of shops and businesses are closed due to the pandemic with the exception of those listed as 'essential' activities. Besides, impermeable interfaces such as blank walls and fences have the affordance of becoming appropriated by street vendors. The lines we draw between different types might seem somewhat arbitrary but can inform more effective guidelines for street vendors in response to the COVID-19 outbreak.

In the midst of the COVID-19 public health crisis, understanding the formal/informal as a non-binary twofold conception in relation to the dynamics of street vending can have considerable impacts on how to give ghostly cities back their pre-crisis vibrant and lively public spaces. Their rights to use and appropriate public space have long been proven to be seminal to the emergence of intensive street life and productive urbanity in many cities and towns in the global South (Bromley 2000; Kamalipour and Peimani 2019b). Hence, such spatial agency cannot be simply overlooked whilst we are raising questions about how social interactions in public spaces are changing. How long such changes endure? To what extent the pandemic crisis can inform the future public space design, use, and management? Will the attention given to such crises distracting us from the challenges urban poor, low-skilled migrants, and the marginalised are facing to stay put and sustain livelihoods? If the authorities wish to turn a blind eye to the severe consequences of the COVID-19 lockdowns on the urban poor and vulnerable groups (mainly those low-skilled migrants in informal food markets), it is likely that the disenfranchised negotiate the ways forward with officials through collective forms of action. Marching against relentless evictions in Thailand (Taylor and Chandran 2020) and protesting to demand payment from Finance Ministry in Thailand (Techakitteranun 2020) are among the emerging practices of collective action gaining widespread visibility, particularly from media.

\section{Informal transport}

Central to the mobility challenges in the context of global South and beyond is the use of different forms of informal transport and their relationships with formal transport, which remain enduring yet relatively under-investigated. Informal transport services have become a burgeoning form of mobility which is geared to their capacity to fill the gaps of the formal public transport services, offer a fast and on-demand mobility, charge reasonable fares, and adapt to shifting market demands (Cervero and Golub 2007; Silcock 1981; Sopranzetti 2014). Their capacities to transgress formal codes of the city and manoeuvre through congested traffic, sidewalks and narrow lanes provide further advantages. The informal transport vehicles are often registered yet are not formally approved for providing transport service to the public (Cervero 2000; Venter 2013). Informal transport not only plays a significant role in facilitating everyday mobilities but also constitutes a key part of a much broader informal economy as they provide job opportunities for the poor and low-skilled rural-to-urban migrants (Sengers and Raven 2014; Tiwari 2005). In this section, we explore the complex informal/formal relations and the dynamics of informal transport to understand how forms of informality negotiate and compete for the use of access networks in the face of the COVID-19 pandemic.

Beyond cities of the global South, the Coronavirus outbreak has also had a considerable impact on the ways in which we travel to places of working, learning, shopping, or entertainment, using a range of private and public modes of transport. At the time of writing this paper, many governments worldwide have taken strict measures to cease nonessential travel and redirect some of the remaining demand (i.e. for key workers and those with essential needs) to limited public transport services or private transport modes. This is mainly because public modes of transport along with shared mobility services such as ride sharing, ride hailing, and scooter sharing, among others, have been regarded as high risk for transmission of the virus (Ibold et al. 2020). 
A study in Hubei, for instance, shows that one can spread Coronavirus to nine people travelling on a bus (Null and Smith 2020). According to recent data, the curfews and individual concerns in order to maintain social distancing have led to plummeting public transit ridership and declined transport demand-i.e. passenger numbers are down $70 \%$ to $90 \%$ (Rubiano and Darido 2020). It has been argued that such measures aimed at relieving local public transport and improving air quality have shown a high consistency between sustainable transport goals and COVID-19 abatement (Ibold et al. 2020).

The COVID-19 challenge offers an opportunity for urban planners to liberate more public space network for pedestrians and cyclists, guiding us towards greener urban environments and low-carbon cities (Nieuwenhuijsen 2020; Roberts 2020). The contours of this debate have opened up critical emerging questions, which can be informative in guiding future research and policy. Parts of the existing access network in many cities have been reconfigured to allocate more space to pedestrians and bikes as streets have become less car dominated and providing public space for urbanities has become more urgent than ever (Arieff 2020). This initiative has become promising in a global context as a reflection moment to rethink city futures in relation to active transport (e.g. Perry 2020; Olin 2020; Laker 2020) and, as such, reimagine urban resilience from a public health perspective.

To fill the gaps of the more formal public transport services and to more easily comply with the 'social distancing' requirement, informal modes of private transport such as bicycles, electric scooters and motorcycles have emerged as reasonably low-risk and affordable alternatives in larger numbers than the pre-outbreak period, particularly in many cities of the global South. Such informal transit services have been considered adaptive in responding to government action plans (e.g. halting or cutting back subsidised formal public transport) and filling the gap for essential workers (de Vries 2020a). Using smaller and more agile vehicles such as bikes affords the capacity to plan your route, avoid narrow and busy areas and think about the time of day you choose for your ride (Gordon 2020). In many cities, the restrictions on the use of more informal private modes of transport have been lifted to support muchneeded mobility, including the use of electric bikes for restaurant take-outs and home food deliveries in New York (Meyer 2020) as well as integrating bike-sharing service with buses in Cardiff (Middleton 2020). Nevertheless, evidence shows that the outbreak is likely to dent the informal transit demand trajectory. There has been considerably less ridership for informal public transit services in the context of the global South-e.g. minivans and buses called matatus in Kenya (Halais 2020), auto-rickshaws in India (Koushik 2020), and minibus drivers in Mexico City (de Vries 2020a). Some governments have also enforced strict measures on the use of these informal transit services. Authorities in South Africa, for instance, banned the use of taxis (local minivans) and then had to partly relax the restrictions (i.e. limiting the number of the passengers to $70 \%$ of the total capacity) following a public outcry (Halais 2020). Tactics of the ordinary have also emerged as a form of resistance and collective action in response to the strategies of the state authorities. Operators and drivers of informal transit services resisted government policies in different ways. In Bangkok, tuk-tuk (three-wheeler motorised vehicles used as taxis) riders have been hit hard by the pandemic and its consequent tourism freeze in public open spaces (Marukatat 2020). The most enduring tactic has been the instantaneous and silent communication established among individual riders with common interests and, as such, banded collectively to offer parcel deliveries and sustain livelihoods countering the COVID-19 crisis.

In the context of the global South, any street redesign and reallocation schemes should take into account the dynamics between different agents such as pedestrians, cyclists, street vendors, and pavement dwellers to more effectively meet the emerging needs and desires besides physical and social distancing. For example, street vendors can use informal modes of transport such as motorcycles to get to places (usually not in proximity to their places of living or working) where they can get the essential goods or permits for their everyday small businesses. They can also more easily get to those curfew areas to set up their businesses. The space restrictions might not change and the competitions/claims for space will persist. Such changes and redesigns will also be reliant on much broader challenges, including mobility choices and local policies as well as road and transport funding mechanisms. Informal transport services and their integration within the emerging city fabric have become critical during the COVID-19 crisis . The pandemic has already become a way that sprawl advocates use to justify more low-density, single-use, car-oriented urban design and using cars is promoted by car companies for being a safer option compared to public transit (Roberts 2020). Hence, moving towards the imperatives of urban intensification and a low-carbon future remains as one of the most significant challenges facing our cities in the context of the pandemic. It is, therefore, important to harness the capacities of informal modes of transport, particularly those that can serve as adaptable, resilient, and flexible alternatives to fossil-fuel-powered vehicles and conventional public transports. Urban design has the capacity to explore the ways in which informal and formal modes of transport can effectively become integrated to facilitate much-needed services without compromising public health and safety in the times of pandemic. 


\section{Discussion and conclusion}

Thus far, we have pointed to a range of spatial and temporal implications of public health emergencies on different forms of informal urbanism, including informal settlements, street vending, and transport, with a focus on the COVID-19 pandemic. In this section, we want to open the discussion on incorporating informality in urban design research on public health. Wholesale approaches, ranging from ignoring to enforcing lockdowns or relentless evictions, fall short in addressing the dynamics of informal urbanism in the face of urban health emergencies. This becomes even more critical during outbreaks as potentials for resistance from local communities are stymied due to strict lockdowns, social isolation, and various types of curfew. The questions of urban informality are associated with typology-different types of informal settlement, informal street vending, and informal transport. Prescribing a fixed solution cannot simply fit all types. Typology can become a key tool for unravelling differences and analysing how places are assembled in relation to forms of informality and public health emergencies. Understanding differences can, in turn, enable a more tailored design and policy interventions rather than enforcing plans for wholesale transformations fuelled by generalised assumptions and action biases with limited supporting evidence.

We argue that providing and adopting a nuanced understanding of urban informality would be critical as informal urbanism is a multiplicity with loose boundaries incorporating forms of informality working across different scales and contexts in relation to formality. It is in this sense that questions of urban informality are also linked to assemblage thinking as a theoretical lens (DeLanda 2016; Deleuze and Guattari 1987; Dovey 2012; Kamalipour and Peimani 2015). Making binary distinctions between 'informal' and 'formal' and other reductionist dichotomies such as 'slum' and 'nonslum' runs the risk of overlooking the in-between conditions and processes through which one becomes another. Generalised interventions at the macro-scale are by no means sufficient as we are dealing with different forms of informal settlements, street vending, and transport crying for tailored approaches across multiple scales with a particular focus on the micro-scale and the relations between different scales.

While the discussion of forms of informality during pandemics such as the COVID-19 cuts across the constructed boundaries between forms of urbanism in the global North and South, it is important to note that the same restrictions enforced in the context of global North cannot be simply extended to cities of the global South. Such narrow measures that fail to consider broader structural elements further raise key questions for the built environment professions seeking to intervene in rapidly urbanising cities. While forms of informality may involve insurgency and tactical resistance, resorting to informality is often a matter of 'necessity' for many people to ensure survival and livelihood rather than a matter of 'choice' or 'option' that can be simply restricted and further justified. This resonates with the distinction made earlier by Devlin (2017) between informality born of 'need' and that born of 'desire' suggesting that urban planning in the context of the global North has much to learn about forms of informality in the global South.

While we also need to avoid conflating informal with tactical and temporal, it is critical to reflect on the productive capacity of tactical and temporal interventions in response to public health emergencies and the extent to which such creative practices can inspire more permanent transformations. Tactical and temporary interventions at the microscale offer low-cost and simple solutions to enable social interactions, reshape cities for people and save urban life in the context of the Coronavirus pandemic (Daly et al 2020). Certain types of public/private interface such as setback, setfront, and setover thresholds have played a key role during the COVID-19 lockdowns in enabling at once social interactions and physical distancing (Iampolski and Novacevski 2020). Forms of street art have also harnessed the expressive capacities of urban design to make certain pandemicrelated narratives visible/invisible across cities by adapting blank walls during the outbreak (Mitman 2020). The task for urban design is then to harness the productive and transformational capacities of tactical and temporary interventions to at once address the needs and desires, particularly those of the more vulnerable communities, and challenge the status quo. Tactical and temporal interventions at the micro-scale can become critical for the survival of informal street vending and transport in the face of public health emergencies such as the COVID-19 outbreak.

Hasty attempts to address the challenge of pandemics through underdeveloped design and policy interventions are often based on a poor understanding of the key urban design conceptions, such as density, accessibility, spatial configuration, mix, type, public/private interface, public space, and street life intensity. This can become even more challenging in the context of informal urbanism as we know very little about how forms of informality work in relation to urban morphology, morphogenesis, and self-organised governance at the micro-scale. Conflating physical distancing with social encounters or confusing building density with population density in terms of jobs or residents can become particularly problematic in the context of urban health emergencies. It has been argued that the correlations between urban density and the resilience to public health emergencies are often blind to the differences between various kinds of density (Pafka 2020). While certain disease outbreaks and health concerns have been historically linked to density and the ways in which cities could be planned (Moore 2020), it has 
been pointed out that neither metropolitan densities nor gross residential densities of neighbourhoods could necessarily reflect the micro-scale dynamics of social interactions that might introduce transmission risks (Pafka 2020). Suburban sprawls are not necessarily safer against the COVID-19 outbreak (Bliss and Capps 2020). It is critical to adopt a more nuanced understanding of the key urban design conceptions such as density and the ways in which places work to explore the capacities of urban design to sustain productive change and adaptation.

Urban mapping has the capacity to inform urban design interventions in the context of health challenges by unravelling how different places work. Mapping cannot be simply reduced to a form of visualisation to represent spatial realities as it has the capacity to unravel the relationships between different elements and explore a disease outbreak as a dynamic spatial process (Koch 2017). As a method, mapping can make invisible features and processes visible (Zakariya 2015). The capacity of medical GIS mapping to explore the links between disease information and spatial data and its advancements regarding big data and space-time representation can effectively contribute to the development of healthcare in a global context (Musa et al. 2013). While the history of mapping outbreaks goes back to the seventeenth century, medical cartography and its democratisation due to technological advancements have taken off in the past decades (Patino 2020). Since pandemics such as the COVID-19 do not equally hit different people, most vulnerable parts of the city can be mapped out by pulling in the latest disease data from reliable sources in relation to other relevant data on poverty or residents who are not living within the walkable catchment of some key amenities such as grocery stores (Peters 2020). Nevertheless, while mapping can reinvigorate the well-being of the urban poor by enabling them to harvest social and economic benefits, it can expose the hidden land market to forms of exploitation often practiced by the real estate developers, land mafia, and speculators (Vardhan Mishra 2019). Urban mapping can also unravel how informal transport works across cities. Mapping has been used as a tool to unravel mobilities of informal transport services across 36 cities worldwide. As such, it has been argued that to simply eliminate (i.e. overlook their agency in urban mobility in the age of Coronavirus) or replace informal transport services will cause more harm than good (de Vries 2020b).

Pandemic crisis often reinforces gender, race, and classbased disparities in access to and use of public space. If the spatial and temporal practices in the age of pandemics remain blind to the pressing challenge of equity in addressing the questions regarding the rights of action, appropriation, and control in public space, they could further exacerbate pre-existing conditions of social division and inequality. Therefore, public space may cease to become an arena for social mixing as the needs of the disenfranchised and vulnerable groups are not accounted for in its design and management. It has been evidenced how the COVID-19 has put a magnifying glass on inequalities both within and between different countries (Kluth 2020). Conspiracy theories targeting religious minorities in public spaces are likely to escalate during the pandemic crisis. In New Delhi, for instance, the digital media has linked the nationwide spread of Coronavirus to Muslim minorities (Ellis-Petersen and Rahman 2020; Menon 2020). It has been argued that the pandemic has been used as an excuse to reinforce economic marginalisation or systematically discriminate against specific public gatherings as well as rights to use public spaces (e.g. blocking access of Muslim vendors to public spaces in certain cities in India such as Haldwani and Mangalore) (Ali 2020). Nevertheless, such practices should also be critically addressed in the context of ongoing tensions between healthcare workers and minorities (Pandey 2020). Economic necessity and employment obligations in the context of the global South have made the urban poor and low-income people to travel in the city and serve the public in the midst of the pandemic crisis. Their activities in the public realm inevitably come into conflict with the desires of the authorities, which tend to control the public health and safety. These issues have also been more or less extended to the context of the global North, such as the United States, where low-income workers cannot simply shift to online and homeworking, which has been contrasted with the high-income skilled workers (Valentino-DeVries et al. 2020). It is, therefore, a wake-up call for authorities to move towards more spatially, socially, and temporally just cities by enabling more equitable approaches to urban transformation, providing equal opportunities (e.g. access to urban amenities, employment and healthcare), and supporting the ordinary to sustain livelihoods and thrive.

The time of crisis is the time for action as much as critical reflection on our capacity to enable creative forms of becoming. Informal urbanism is here to stay as an open multiplicity and cannot be simply wished away. While forms of informality are by no means limited to the global South, it is critical to move towards an informal turn in exploring the intersections between urban design and health in order to deterritorialise the related body of knowledge and extend it beyond the global North. More research on the intersections between urban design, health, and informal urbanism can potentially enable an evidence-based approach to design interventions in response to public health emergencies such as the COVID-19 pandemic. This can range from action research and design research to research-based design interventions by drawing on a nuanced understanding of how forms of informality work before jumping into any conclusion regarding design intervention and its impacts. Moving towards an informal turn in urban design education is then critical as it has the capacity to challenge the constructed conceptions 
of informality and forms of reductionism (Kamalipour and Peimani 2019a). Challenging the policy settings and conventional conceptions among students, governments and the general public remains a key task for educators and academics to provide a better understanding of how 'self-organised city' works through teaching and research (Jones 2020). Our exploration in this paper can serve as an initial step in this regard. Urban design in the face of public health emergencies has the capacity to challenge forms of micro and macro reductionism by focusing on complex relations between informal and formal across different scales and contexts.

\section{References}

Acuto, M. 2020. COVID-19: Lessons for an urban(izing) world. One Earth 2: 317-319. https://doi.org/10.1016/j.oneear.2020.04.004.

Ahmed, S., et al. 2019a. Does urbanization make emergence of zoonosis more likely? Evidence, myths and gaps. Environment and Urbanization 31 (2): 443-460. https://doi.org/10.1177/09562 47819866124.

Ahmed, S., et al. 2019b. Participatory mapping and food-centred justice in informal settlements in Nairobi, Kenya. Geo 6 (1): 1-21. https://doi.org/10.1002/geo2.77.

Ali, A. 2020. Covid an excuse to push Indian Muslims out of informal sector jobs. Apartheid the next step. ThePrint, 9 April. https:// theprint.in/opinion/covid-an-excuse-to-push-indian-muslimsout-of-informal-sector-jobs-apartheid-the-next-step/398236. Accessed 28 June 2020.

Arefi, M. 2011. Order in informal settlements: A case study of Pinar Istanbul. Built Environment 37 (1): 42-56. https://doi. org/10.2148/benv.37.1.42.

Arefi, M., and C. Kickert, eds. 2019. The palgrave handbook of bottom-up urbanism. Cham: Palgrave Macmillan. https://doi. org/10.1007/978-3-319-90131-2.

Arieff, A. 2020. The magic of empty streets: Social distancing gives us a rare chance to fix cities. The New York Times, 8 April. https ://www.nytimes.com/2020/04/08/opinion/coronavirus-tips-newyork-san-francisco.html. Accessed 28 June 2020.

Bird, J., et al. 2017. Life in a slum: Understanding living conditions in Nairobi's slums across time and space. Oxford Review of Economic Policy 33 (3): 496-520. https://doi.org/10.1093/oxrep/ grx036.

Bliss, L., and K. Capps. 2020. Are suburbs safer from coronavirus? Probably not. Bloomberg, 13 March. https://www.bloomberg. com/news/articles/2020-03-13/are-suburbs-safer-from-coron avirus-probably-not. Accessed 28 June 2020.

Bowyer, R., et al. 2020. Geo-social gradients in predicted COVID-19 prevalence and severity in Great Britain: Results from 2,266,235 users of the COVID-19 Symptoms Tracker app. MedRxiv. https ://doi.org/10.1101/2020.04.23.20076521.

Bromley, R. 2000. Street vending and public policy: A global review. International Journal of Sociology and Social Policy 20 (1/2): 1-28. https://doi.org/10.1108/01443330010789052.

Cervero, R. 2000. Informal transport in the developing world. Nairobi: UN-HABITAT.

Cervero, R., and A. Golub. 2007. Informal transport: A global perspective. Transport Policy 14 (6): 445-457. https://doi.org/10.1016/j. tranpol.2007.04.011.

Chalana, M. 2019. Urban design and informal urbanism. In The new companion to urban design, eds. T. Banerjee and A.
Loukaitou-Sideris, 175-188. New York: Routledge. https://doi. org/10.4324/9780203731932-18.

Chen, M.A. 2020. Vegetables on wheels in Ahmedabad, India: SEWA partners with municipality to ensure food access during lockdown. WIEGO blogs, 5 May, https://www.wiego.org/blog/veget ables-wheels-ahmedabad-india-sewa-partners-municipalityensure-food-access-during. Accessed 28 June 2020.

Chen, J., et al. 2016. Effect of modelling slum populations on influenza spread in Delhi. British Medical Journal Open 6 (9): 1-8. https ://doi.org/10.1136/bmjopen-2016-011699.

Corburn, J., et al. 2020. Slum health: Arresting COVID-19 and improving well-being in urban informal settlements. Journal of Urban Health 97: 348-357. https://doi.org/10.1007/s11524-020-00438 $-6$.

Daly, J., et al. 2020. We can't let coronavirus kill our cities. Here's how we can save urban life. The Conversation, 5 May. https://theco nversation.com/we-cant-let-coronavirus-kill-our-cities-heres -how-we-can-save-urban-life-137063. Accessed 28 June 2020.

DeLanda, M. 2006. A new philosophy of society: Assemblage theory and social complexity. New York: Continuum.

DeLanda, M. 2016. Assemblage theory. Edinburgh: Edinburgh University Press.

Deleuze, G., and F. Guattari. 1987. A thousand plateaus: Capitalism and schizophrenia. Minneapolis: University of Minnesota Press.

de Vries, D. 2020a. In emerging-market megacities, informal public transport shines during the crisis. CityMetric, 7 May. https:// www.citymetric.com/transport/emerging-market-megacities -informal-public-transport-shines-during-crisis-5063. Accessed 28 June 2020.

de Vries, D. 2020b. Informal public transport: Front-line mobility heroes. Medium, 18 May. https://medium.com/@mytransport/ informal-public-transport-front-line-mobility-heroes-f7666e $5 \mathrm{~d} 3 \mathrm{f}$ d9. Accessed 28 June 2020.

Devlin, R.T. 2017. Asking 'Third World questions' of First World informality: Using Southern theory to parse needs from desires in an analysis of informal urbanism of the global North. Planning Theory 17 (4): 568-587. https://doi.org/10.1177/1473095217 737347.

Dovey, K. 2010. Becoming places: Urbanism/architecture/identity/ power. London: Routledge. https://doi.org/10.4324/9780203875 001.

Dovey, K. 2012. Informal urbanism and complex adaptive assemblage. International Development Planning Review 34 (4): 349-368. https://doi.org/10.3828/idpr.2012.23.

Dovey, K., and R. King. 2011. Forms of informality: Morphology and visibility of informal settlements. Built Environment 37 (1): 11-29. https://doi.org/10.2148/benv.37.1.11.

Dovey, K., and H. Kamalipour. 2018. Informal/formal morphologies. In Mapping urbanities: Morphologies, flows, possibilities, eds. K. Dovey, et al., 223-248. New York: Routledge. https://doi. org/10.4324/9781315309163-13.

Dovey, K., et al., eds. 2018. Mapping urbanities: Morphologies, flows, possibilities. New York: Routledge. https://doi. org/10.4324/9781315309163.

Ellis-Petersen, H., and S.A. Rahman. 2020. Coronavirus conspiracy theories targeting Muslims spread in India. The Guardian, 13 April, https://www.theguardian.com/world/2020/apr/13/coron avirus-conspiracy-theories-targeting-muslims-spread-in-india. Accessed 28 June 2020.

Ezeh, A., et al. 2017. The history, geography, and sociology of slums and the health problems of people who live in slums. The Lancet 389 (10068): 547-558. https://doi.org/10.1016/S0140 $-6736(16) 31650-6$.

Gordon, S. 2020. Coronavirus: A guide to social distancing and cycling. Cycling UK, 16 April. https://www.cyclinguk.org/artic 
le/coronavirus-guide-social-distancing-and-cycling. Accessed 28 June 2020.

Halais, F. 2020. Informal transit is crucial for some. Can it weather covid-19? Wired, 24 May, https://www.wired.com/story/infor mal-transit-crucial-can-weather-covid-19. Accessed 28 June 2020.

Hasan, A. 2020. Karachi, informal settlements and COVID-19. International Institute for Environment and Development, 6 May. https://www.iied.org/karachi-informal-settlements-covid-19. Accessed 28 June 2020.

Hooper, M. 2020. Pandemics and the future of urban density: Michael Hooper on hygiene, public perception and the "urban penalty". Harvard University Graduate School of Design News, 13 April. https://www.gsd.harvard.edu/2020/04/havewe-embraced-urban-density-to-our-own-peril-michael-hoope r-on-hygiene-public-perception-and-the-urban-penalty-in-aglobal-pandemic. Accessed 28 June 2020.

Iampolski, R., and M. Novacevski. 2020. A time to embrace the edge spaces that make our neighbourhoods tick. The Conversation, 31 May. https://theconversation.com/a-time-to-embra ce-the-edge-spaces-that-make-our-neighbourhoods-tick-13882 6 ?utm_source $=$ twitter\&utm_medium $=$ bylinetwitterbutton. Accessed 28 June 2020.

Ibold, S., et al. 2020. The COVI-19 outbreak and implications to sustainable urban mobility-Some observations. TUMI, 3 April. https://www.transformative-mobility.org/news/the-covid-19outbreak-and-implications-to-public-trans port-some-obser vations. Accessed 28 June 2020.

Iveson, K. 2020. We don't know what we've got till it's gone-We must reclaim public space lost to the coronavirus crisis. The Conversation, 15 April, https://theconversation.com/we-dontknow-what-weve-got-till-its-gone-we-must-reclaim-publi c-space-lost-to-the-coronavirus-crisis-135817. Accessed 28 June 2020.

Jabareen, Y. 2014. "Do it yourself" as an informal mode of space production: Conceptualizing informality. Journal of Urbanism: International Research on Placemaking and Urban Sustainability 7 (4): 414-428. https://doi.org/10.1080/17549175.2014.88497 5.

Jones, P. 2019. The shaping of form and structure in informal settlements: A case study of order and rules in Lebak Siliwangi, Bandung, Indonesia. Journal of Regional and City Planning 30 (1): 43-61. https://doi.org/10.5614/jpwk.2019.30.1.4.

Jones, P. 2020. Too many left behind: the failing of COVID-19 prevention measures in informal settlements and slums. The Conversation, 4 May, https://theconversation.com/too-many-left-behin d-the-failing-of-covid-19-prevention-measures-in-informal-settl ements-and-slums-137288. Accessed 28 June 2020.

Kamalipour, H., and K. Dovey. 2018. Incremental urbanisms. In Mapping urbanities: Morphologies, flows, possibilities, eds. K. Dovey, et al., 249-267. New York: Routledge. https://doi. org/10.4324/9781315309163-14.

Kamalipour, H., and K. Dovey. 2019. Mapping the visibility of informal settlements. Habitat International 85: 63-75. https://doi. org/10.1016/j.habitatint.2019.01.002.

Kamalipour, H., and K. Dovey. 2020. Incremental production of urban space: A typology of informal design. Habitat International 98: 102133. https://doi.org/10.1016/j.habitatint.2020.102133.

Kamalipour, H., and N. Peimani. 2015. Assemblage thinking and the city: Implications for urban studies. Current Urban Studies 3 (4): 402-408. https://doi.org/10.4236/cus.2015.34031.

Kamalipour, H., and N. Peimani. 2019a. Towards an informal turn in the built environment education: Informality and urban design pedagogy. Sustainability 11 (15): 4163. https://doi.org/10.3390/ su11154163.
Kamalipour, H., and N. Peimani. 2019b. Negotiating space and visibility: Forms of informality in public space. Sustainability 11 (17): 4807. https://doi.org/10.3390/su11174807.

Kluth, A. 2020. This pandemic will lead to social revolutions. Bloomberg, 11 April, https://www.bloomberg.com/opinion/artic les/2020-04-11/coronavirus-this-pandemic-will-lead-to-socia 1-revolutions. Accessed 28 June 2020.

Koch, T. 2017. Cartographies of disease: Maps, mapping, and medicine. Redlands: ESRI Press.

Koushik, J. 2020. Chennai lockdown: All you need to know on e-passes, travel restrictions. The Indian Express, 18 June. https ://indianexpress.com/article/cities/chennai/chennai-lockdownall-you-need-to-know-on-e-passes-travel-restrictions-6464803. Accessed 28 June 2020.

Lara-Hernandez, J.A., et al. 2020. Temporary appropriation and urban informality: Exploring the subtle distinction. Cities 99: 102626. https://doi.org/10.1016/j.cities.2020.102626.

Latour, B. 2020. Is this a dress rehearsal? Critical Inquiry, 26 March. https://critinq.wordpress.com/2020/03/26/is-this-a-dress-rehea rsal. Accessed 28 June 2020.

Laker, L. 2020. World cities turn their streets over to walkers and cyclists. The Guardian, 11 April. https://www.theguardian.com/ world/2020/apr/11/world-cities-turn-their-streets-over-to-walke rs-and-cyclists. Accessed 28 June 2020.

Lilford, R.J., et al. 2017. Improving the health and welfare of people who live in slums. The Lancet 389 (10068): 559-570. https://doi. org/10.1016/S0140-6736(16)31848-7.

Lilford, R.J., et al. 2019. Because space matters: Conceptual framework to help distinguish slum from non-slum urban areas. British Medical Journal Global Health 4 (2): 1-7. https://doi.org/10.1136/ bmjgh-2018-001267.

Marukatat, S. 2020. Tuk-tuks turn from tourist darling to parcel delivery. Bangkok Post, 8 April, https://www.bangkokpost.com/busin ess/1895780/tuk-tuks-turn-from-tourist-darling-to-parcel-deliv ery. Accessed 28 June 2020.

Marx, C., and E. Kelling. 2018. Knowing urban informalities. Urban Studies 56 (3): 494-509. https://doi.org/10.1177/0042098018 770848 .

Mayne, A. 2017. Slums: The history of a global injustice. London: Reaktion.

McTernan, B.A. 2014. Accra slum dwellers suspect cholera demolitions are a pretext for profit. The Guardian, $20 \mathrm{Oct}$, https://www. theguardian.com/global-development/2014/oct/20/accra-chole ra-ghana-mensah-guinea-slums-demolished-commercial-profit. Accessed 28 June 2020.

Menon, A. 2020. Attacks on Muslims in the name of COVID-19 surge across India. The Quint, 8 April. https://www.thequint.com/news/ india/coronavirus-muslims-attacked-covid19-karnataka-haryana. Accessed 16 Sept 2020.

Meyer, D. 2020. NYC suspends e-bike crackdown as eateries move to takeout, delivery-only. New York Post, 16 March, https://nypos t.com/2020/03/16/nyc-suspends-e-bike-crackdown-as-eateriesmove-to-takeout-delivery-only. Accessed 28 June 2020.

Middleton, N. 2020. Cardiff collaboration teams up bike share scheme with bus app. Fleetworld, 18 May, https://fleetworld.co.uk/cardi ff-collaboration-teams-up-bike-share-scheme-with-bus-app. Accessed 28 June 2020.

Mitlin, D. 2020. Dealing with COVID-19 in the towns and cities of the global South. International Institute for Environment and Development, 27 March. https://www.iied.org/dealing-covid-19-towns -cities-global-south. Accessed 28 June 2020.

Mitman, T. 2020. Coronavirus murals: Inside the world of pandemicinspired street art. The Conversation, 18 May. https://theconvers ation.com/coronavirus-murals-inside-the-world-of-pandemicinspired-street-art-138487. Accessed 28 June 2020. 
Moore, R. 2020. Will Covid-19 show us how to design better cities? The Guardian, 24 May, https://www.theguardian.com/socie ty/2020/may/24/will-covid-19-show-us-how-to-design-bette r-cities. Accessed 28 June 2020.

Muggah, R., and R. Florida. 2020. Megacity slums are incubators of disease-But coronavirus response isn't helping the billion people who live in them. The Conversation, 14 May, https://theco nversation.com/megacity-slums-are-incubators-of-disease-butcoronavirus-response-isnt-helping-the-billion-people-who-livein-them-138092. Accessed 28 June 2020.

Mukhija, V. 2011. Urban design for a planet of informal cities. In Companion to urban design, eds. T. Banerjee and A. Loukaitou-Sideris, 574-584. New York: Routledge.

Musa, G.J., et al. 2013. Use of GIS mapping as a public health tool-From cholera to cancer. Health Services Insights 6: 111-116. https://doi.org/10.4137/HSI.S10471.

Neuwirth, R. 2011. Stealth of nations: The global rise of the informal economy. New York: Pantheon Books.

Nieuwenhuijsen, M.J. 2020. Urban and transport planning pathways to carbon neutral, liveable and healthy cities; A review of the current evidence. Environment International 140: 105661. https://doi.org/10.1016/j.envint.2020.105661.

Null, S., and H. Smith. 2020. COVID-19 could affect cities for years. Here are 4 ways they're coping now. TheCityFix, 20 March, https://thecityfix.com/blog/covid-19-affect-cities-years -4-ways-theyre-coping-now-schuyler-null-hillary-smith. Accessed 28 June 2020.

Nyein, N. 2020. Myanmar town finds way to protect market vendors, customers amid COVID-19. The Irrawaddy, 28 April, https ://www.irrawaddy.com/specials/myanmar-covid-19/myanm ar-town-finds-way-protect-market-vendors-customers-amidcovid-19.html. Accessed 28 June 2020.

Olin, A. 2020. Dear cities: Don't miss this once-in-a-lifetime opportunity to remake and retake streets. The Kinder Institute for Urban Research, 25 April, https://kinder.rice.edu/urban edge/2020/04/25/Coronavirus-transportation-Houston-citystreets-closed. Accessed 28 June 2020.

Olsen, H. 2020. The United States might have a secret weapon against coronavirus. The Washington Post, 19 March. https:// www.washingtonpost.com/opinions/2020/03/19/united-state s-might-have-secret-weapon-against-coronavirus. Accessed 28 June 2020.

Pafka, E. 2020. As coronavirus forces us to keep our distance, city density matters less than internal density. The Conversation, 12 May, https://theconversation.com/as-coronavirus-forces-us-tokeep-our-distance-city-density-matters-less-than-internal-densi ty-137790. Accessed 28 June 2020.

Pandey, V. 2020. Coronavirus: India doctors 'spat at and attacked'. BBC News, 3 April, https://www.bbc.co.uk/news/world-asiaindia-52151141. Accessed 16 Sept 2020.

Pardeshi, P., et al. 2020. Association between architectural parameters and burden of tuberculosis in three resettlement colonies of M-East Ward, Mumbai, India. Cities \& Health. https://doi. org/10.1080/23748834.2020.1731919.

Patino, M. 2020. Coronavirus outbreak maps rooted in history. Bloomberg, 11 Feb, https://www.bloomberg.com/news/articles/202002-11/coronavirus-outbreak-maps-rooted-in-history. Accessed 28 June 2020.

Perry, F. 2020. How cities are clamping down on cars. BBC Future Planet, 30 April, https://www.bbc.com/future/article/20200 429-are-we-witnessing-the-death-of-the-car. Accessed 28 June 2020.

Peters, A. 2020. This tool is helping cities find the neighborhoods most vulnerable to coronavirus. Fastcompany, 3 March, https ://www.fastcompany.com/90481120/this-tool-is-helping-citie s-find-the-neighborhoods-most-vulnerable-to-coronavirus. Accessed 28 June 2020.

Pinto, V.S. 2020. With no income and food, Dharavi gasps for air as Covid-19 cases increase. Business Standard, 6 April, https ://www.business-standard.com/article/current-affairs/dhara vi-asia-s-largest-slum-holds-its-breath-as-covid-19-cases-riseto-5-120040500945_1.html. Accessed 28 June 2020.

Priyadarshini, A., and S. Chaudhury. 2020. The return of Bihari migrants after the COVID-19 lockdown. In Borders of an epidemic COVID-19 and migrant workers, ed. R. Samaddar, 66-75. Kolkata: Calcutta Research Group Publication.

Qian, H., et al. 2020. Indoor transmission of SARS-CoV-2. MedRxiv. https://doi.org/10.1101/2020.04.04.20053058.

Ribeiro, G. 1997. An ecological approach to the study of urban spaces: The case of a shantytown in Brasilia. Journal of Architectural and Planning Research 14 (4): 289-300.

Roberts, D. 2020. How to make a city livable during lockdown. Vox, 22 April, https://www.vox.com/cities-and-urban ism/2020/4/13/21218759/coronavirus-cities-lockdown-covid -19-brent-toderian. Accessed 28 June 2020.

Rosenthal, B. 2020. Density is New York City's big 'enemy' in the coronavirus fight. The New York Times, 23 March. https://www. nytimes.com/2020/03/23/nyregion/coronavirus-nyc-crowd s-density.html. Accessed 28 June 2020.

Roy, A. 2015. Urban informality: The production and regulation of space. In International encyclopedia of the social \& behavioral sciences, 2nd ed., ed. J.D. Wright, 818-822. Oxford: Elsevier. https://doi.org/10.1016/B978-0-08-097086-8.74051-7.

Roy, A. 2005. Urban informality: Toward an epistemology of planning. Journal of the American Planning Association 71 (2): 147-158. https://doi.org/10.1080/01944360508976689.

Rubiano, L.C., and G. Darido. 2020. Protecting public transport from the coronavirus... and from financial collapse. World Bank Blogs, 24 April, https://blogs.worldbank.org/transport/ protecting-public-transport-coronavirus-and-financial-colla pse. Accessed 28 June 2020.

Sanderson, D. 2020. Coronavirus an 'existential threat' to Africa and her crowded slums. The Conversation, 9 April. https:// theconversation.com/coronavirus-an-existential-threat-to-afric a-and-her-crowded-slums-135829. Accessed 28 June 2020.

Sengers, F., and R. Raven. 2014. Metering motorbike mobility: Informal transport in transition? Technology Analysis and Strategic Management 26 (4): 453-468. https://doi.org/10.1080/09537 325.2013.870991.

Silcock, D.T. 1981. Urban paratransit in the developing world. Transport Reviews 1 (2): 151-168. https://doi.org/10.1080/01441 648108716456.

Sopranzetti, C. 2014. Owners of the map: Mobility and mobilization among motorcycle taxi drivers in Bangkok. City \& Society 26 (1): 120-143. https://doi.org/10.1111/ciso.12030.

Taylor, F. 2020. How do you manage COVID-19 with a population density of 130,000 people per square kilometre? King's College London, 29 April, https://www.kcl.ac.uk/how-do-youmanage-covid-19-with-a-population-density-of-130000-peopl e-per-square-kilometre. Accessed 28 June 2020.

Taylor, M., and R. Chandran. (2020) Asia's street food hawkers struggle during coronavirus lockdowns. Reuters, 25 March. https://www.reuters.com/article/health-coronavirus-asia/asias -street-food-hawkers-struggle-during-coronavirus-lockdownsidUSL4N2BH2ZA. Accessed 28 June 2020.

Techakitteranun, H. 2020. Millions of Thais left out of government's Covid-19 cash relief scheme. The Straits Times, 17 April, https ://www.straitstimes.com/asia/se-asia/millions-of-thais-leftout-of-governments-covid-19-cash-relief-scheme. Accessed 28 June 2020 
Tiwari, G. 2005. Self-organizing systems and innovations in Asian cities. In Urban transport development, eds. G. Jönson and E. Tengström, 144-157. Berlin: Springer. https://doi. org/10.1007/3-540-27761-7_13.

Tonkiss, F. 2013. Cities by design: The social life of urban form. Cambridge: Polity.

UN-HABITAT. 2020. Key messages: COVID and informal settlements. UN-HABITAT publications, https://unhabitat.org/sites /default/files/2020/03/english_final_un-habitat_key_messa ges-covid19-informal_settlements.pdf. Accessed 28 June 2020.

UN-HABITAT. 2006. The state of the world's cities report 2006/7: The Millennium Development Goals and urban sustainability. London: Earthscan.

Valentino-DeVries, J., et al. 2020. Location data says it all: Staying at home during coronavirus is a luxury. The New York Times, 3 April. https://www.nytimes.com/interactive/2020/04/03/us/coron avirus-stay-home-rich-poor.html. Accessed 28 June 2020.

Vardhan Mishra, S. 2019. Dispossession by appropriation in a global south city: Geography, cartography and statutory regime as mediating factors. International Journal of Urban Sciences 23 (1): 105-121. https://doi.org/10.1080/12265934.2018.1443397.

Venter, C. 2013. The lurch towards formalisation: Lessons from the implementation of BRT in Johannesburg, South Africa. Research in Transportation Economics 39 (1): 114-120. https://doi. org/10.1016/j.retrec.2012.06.003.

Wahba, S. et al. 2020. Cities are on the front lines of COVID-19. World Bank Sustainable Cities blog, 12 May. https://blogs.worldbank. org/sustainablecities/cities-are-front-lines-covid-19. Accessed 28 June 2020.

Wertheim-Heck, S. 2020. The impact of the COVID-19 lockdown on the diets of Hanoi's urban poor. International Institute for
Environment and Development, 8 April. https://www.iied.org/ impact-covid-19-lockdown-diets-hanois-urban-poor. Accessed 28 June 2020.

Weston, M. 2020. How to tackle coronavirus in slums. Global Dashboard, 27 March, https://www.globaldashboard.org/2020/03/27/ how-to-tackle-coronavirus-in-slums. Accessed 28 June 2020.

Wilkinson, A. 2020a. Local response in health emergencies: Key considerations for addressing the COVID-19 pandemic in informal urban settlements. Environment and Urbanization 32 (2): 503 522. https://doi.org/10.1177/0956247820922843.

Wilkinson, A. 2020b. What is the impact of COVID-19 in informal settlements? LSE blogs, 13 March. https://blogs.lse.ac.uk/africaatls e/2020/03/13/what-is-the-impact-of-covid-19-coronavirus-infor mal-settlements-africa. Accessed 28 June 2020.

Zakariya, K. 2015. Mapping Kuala Lumpur's urban night markets at shifting scales. In Informal urban street markets: International perspectives, eds. C. Evers, and K. Seale, 124-135. New York: Routledge.

Zane, D. 2020. Coronavirus: What African countries are doing to help people to eat amid the lockdowns. BBC News, 28 April. https ://www.bbc.co.uk/news/world-africa-52426040. Accessed 28 June 2020.

Publisher's Note Springer Nature remains neutral with regard to jurisdictional claims in published maps and institutional affiliations. 